\title{
Childhood Testicular Mixed Germ Cell Tumor
}

National Cancer Institute

\section{Source}

National Cancer Institute. Childhood Testicular Mixed Germ Cell Tumor. NCI Thesaurus.

Code C6542.

A malignant mixed germ cell neoplasm that arises from the testis during childhood. 